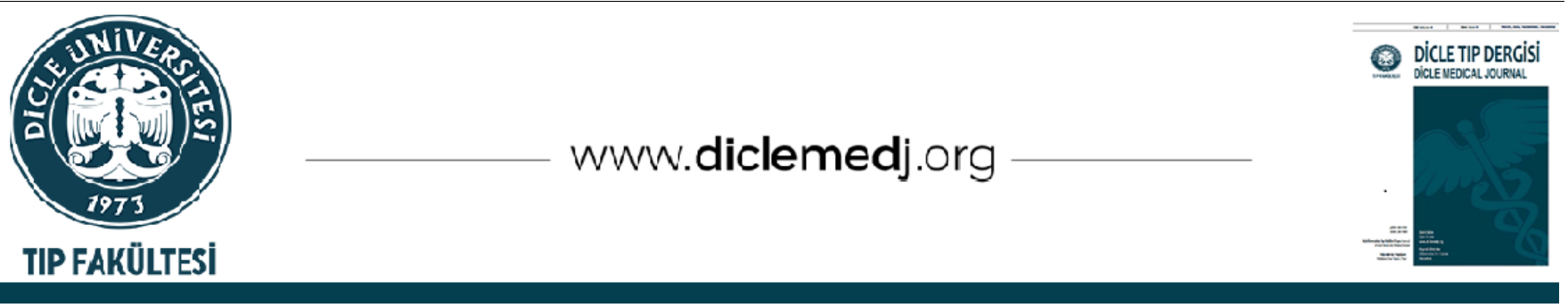

Özgün Araştırma / Original Article

\title{
Kondiloma Akuminata'nın Kriyoterapi ve Cerrahi Eksizyon ile Kombine Tedavisinin Etkinliğinin ve Güvenirliğinin Değerlendirilmesi
}

\author{
Hamza Aktaş ${ }^{1}$, Zeynep Şener Bahçe ${ }^{D}{ }^{2}$, Ebral Yiğit ${ }^{D}{ }_{3}$ \\ 1 Özel Memorial Diyarbakır Hastanesi Dermatoloji Kliniği, Diyarbakır, Türkiye \\ 2 Özel Memorial Diyarbakır Hastanesi Genel Cerrahi Kliniği, Diyarbakır, Türkiye \\ 3 SBÜ Gazi Yaşargil Eğitim ve Araştırma Hastanesi Genel Cerrahi Kliniği, Diyarbakır, Türkiye \\ Geliş: 09.07.2021; Revizyon: 09.11.2021; Kabul Tarihi: 10.11.2021
}

Öz

Giriş: Kondiloma Akuminata (KA), Human Papiloma Virüs'ün (HPV) yol açtığı, cinsel yolla bulaşan, yaygın bir viral hastalıktır. Kondiloma Akuminata'nın tedavisi için çeșitli yöntemler olmakla birlikte, bunların hiçbiri \%100 yanıt oranına ulaşamaz. Bu çalışmada daha iyi yanıt oranı ve rekürrensin engellenmesi için, ablatif sıvı azot kriyoterapisi ile elektrokoter ile cerrahi eksizyonun birlikte kullanımının etkinliği ve nüks oranları değerlendirilmeye çalıșlldı.

Amaç: Kondiloma Akuminata tedavisinde kriyoterapi ile birlikte cerrahinin sinerjistik etkisini değerlendirmek.

Yöntemler: Bu retrospektif çalışmada, Kondiloma Akuminata (lokalize veya yayılmış) tanısı ile dermatoloji kliniğine başvurmuş perianal lezyonları olan ve lezyonları perianal bölge ile birlikte anal dentata kadar uzanan hastalar değerlendirildi. Kriyoterapi ile tedavi edilen küçük lezyonların yanısıra büyüklüğü $4 \mathrm{~cm}$ 'den büyük olan hastalarda cerrahi olarak eksizyonel yöntemler kullanıldı.

Bulgular: Çalışmaya alınan 57 hastanın 33'ü kadın, 24'ü erkekti. Ortalama yaş 27,2 olarak saptandı. Hastaların 51'i tedaviye devam etti. Tüm hastalara kriyoterapi başlandı, 14 hastada ek olarak topikal imiquimod başlandı, 10 hastada lezyonlar anal dentata kadar uzanım gösterdiğinden ve boyutları $4 \mathrm{~cm}$ 'nin üzerinde olduğu için, cerrahi olarak elektrokoterizasyon uygulandı. Kriyoterapi yapılan hastalarda nüks \%24,3 iken, hem kriyoterapi yapılan, hem de imiquimod kullanılan hastalarda bu oran \%21,4 idi. Cerrahi uygulanan hastaların beșinde 3. ayda rekürrens geliști ve bu hastalar tekrar cerrahi tedaviye alındılar. Takiplerinde bir hastada nüks saptandı. Uygulanan tedavilerde ciddi bir komplikasyon gelişmedi.

Sonuç: Yaptığımız çalışma sonucunda anatomik lokalizasyon ve lezyonun büyüklüğünün KA'nın tedavisinde belirleyici olduğu ve kriyoterapiye ek olarak yapılan cerrahinin nüks oranlarını azalttığı tespit edildi.

Anahtar kelimeler: Kondiloma Akuminata, kriyoterapi, cerrahi eksizyon, rekürrens

DOI: 10.5798/dicletip.1037808

Yazışma Adresi / Correspondence: Hamza Aktaş, Fırat Bulvarı Peyas Mahallesi No:12 Kayapınar/Diyarbakır, Türkiye e-mail: drhamzaaktas21@gmail.com 


\section{Evaluation of The Effectiveness and Reliability of Combined Treatment of The Condyloma Acuminata With Cryotherapy and Surgical Excision}

\section{Abctract}

Objective: Condyloma Akuminata (CA) is most common sexually transmitted viral disease caused by Human Papiloma Virus (HPV). Although there are various methods for the treatment of Condyloma Acuminata, none of them can reach $100 \%$ response rate. İn this study, for better response rate and low recurrence, efficacy of ablative liquid nitrogen cryotherapy and electrocautery with surgical excision and recurrence rates were tried to be evaluated.

Aim: This studies purpose to evaluate the synergistic effect of surgery with cryotherapy in the treatment of condyloma acuminata.

Method: In this retrospective study, patients with a diagnosis of Condyloma Acuminata (localized or spread) who applied to the dermatology clinic and whose lesions extend to the anal denta with the perianal region are evaluated. In addition to small lesions treated with cryotherapy, surgical excisional methods were used in patients larger than $4 \mathrm{~cm}$ in size.

Result: This study included 57 patients, 33 were female and 24 were male. The average age was 27.2 years. 51 of the patients continued treatment. Cryotherapy was applied to all patients, additional topical imiquimod was applied in 14 patients, and 10 patients underwent surgical electrocauterization, as the lesions extended to the anal dentate and their dimensions were over $4 \mathrm{~cm}$. While recurrence was $24.3 \%$ in patients undergoing cryotherapy, this rate was $21.4 \%$ in patients undergoing cryotherapy and imiquimod. Five of the patients who underwent surgery developed recurrence at the 3rd month and these patients were taken into surgical treatment again. Recurrence was detected in one patient during follow-up. No serious complications developed in the treatments applied.

Conclusion: As a result of our study, it was found that anatomical localization and the size of the lesion were determinant in the treatment of CA and surgery performed in addition to cryotherapy reduced recurrence rates.

Keywords: Condyloma Acuminata, cryotherapy, surgical excision, recurrence.

\section{GİRIŞ}

Kondiloma Akuminata (KA), etiyolojisinde Human Papilloma Virüs'ün ( HPV) yer aldığı, anogenital bölgede yaygın siğillerle seyreden viral bir hastalıktır. En sık cinsel yolla bulaşır. Kuluçka süresi 2 hafta ila 8 ay arasında değişmektedir ${ }^{1}$.

HPV yaklaşık \%60 oranında cinsel yolla bulaşmakla beraber, materno-fetal yolla da geçiş görülebilir ${ }^{2}$. Klinik olarak tanı konan hasta sayısı 1980'lerden bugüne artmıștır. Ayrıca, birçok tedavi yöntemi olmasına rağmen, nüks oranları artmaya devam etmiș ve bugüne kadar HPV enfeksiyonunu ortadan kaldırma girişimleri başarısız olmuştur ${ }^{3}$.

Çalışmalar, KA'nın nüks oranının \%4,6-70 arasında olduğunu bildirmiștir. HPV'in prevalansı \%11-12 kadardır. Nüks oranının yüksek olması ve tedavisinin zorluğu nedeniyle dünyada hala önemli bir sağlık problemi olmaya devam etmektedir ${ }^{4-6}$.

Ayrica, tekrarlayan HPV enfeksiyonunun servikal, vulvar ve anal karsinomlar ve diğer genital tümör tipleri ile yakından ilişkili olduğu bildirilmiştir. Bu nedenle, HPV enfeksiyonunun kontrolü, tıp, farmakoloji ve biyoloji alanlarında bilim insanlarının önemli bir sorunu haline gelmiștir ${ }^{6,7}$.

\section{YÖNTEMLER}

Çalışmaya Mayıs 2018-Nisan 2019 tarihleri arasında Dermatoloji kliniğinde KA tanısı alan 57 hasta alındı. Hastaların dosyaları retrospektif olarak değerlendirildi. Çalışmada dermatoloji kliniğine başvuran ve tedavi edilen hastalar ile genel cerrahiye yönlendirilen hastaların takipleri ve tedavi sonuçları değerlendirildi. 16 yaş altındaki hastalar çalışma dışı bırakıldı. Hastalardan tıbbi verilerinin yayınlanabileceğine ilişkin yazılı 
onam belgesi alındı. Çalışma için Sağlık Bilimleri Üniversitesi Gazi Yaşargil Eğitim ve Araştırma Hastanesi Etik Kurulundan onay alındı (02/07/2021-813).

Kriyoterapide lezyonlar ilk önce $\% 0,02$ povidon iyot çözeltisi ile temizlendi. Daha sonra, azot tabancası (CryoPro CTX-MAXI 500 Liquid Nitrogen Cryosurgical Spray, Smedevaenget 109560 Hadsund, Denmark) kullanılarak lezyonlara sıvı azot püskürtüldü. Kriyoterapi tabancası ucu ile lezyon arasındaki mesafe 1-2 $\mathrm{cm}$ olacak şekilde uygulama yapıldı. Püskürtme süresi 10-30 saniye arasındaydı ve lezyon çevresinde yaklaşık 2-3 mm'lik donma hattı oluşuncaya kadar püskürtme devam ettirildi. Büyük olan lezyonlarda erime oluştuktan sonra bir siklus daha uygulama yapıldı. Hasta ağrı hissettiğinde püskürtme durduruldu. İşlemden sonra hastalara tedavi edilen alanları günlük olarak incelemeleri, yara yerinde herhangi bir kızarıklık, ağrı, akıntı olması durumunda tekrar başvurması önerildi.

Cerrahi işlem için hastalara spinal anestezi uyguland, cerrahi alan \% 0,02 povidon iyot çözeltisi ile temizlendi. Daha sonra elektrokoter ile lezyon eksize edildi ve tabandaki yağ dokusu koterize edildi. Kanama kontrolü sağlandıktan sonra uygulamaya son verildi. Koterizasyon sırasında viral saçılım olabileceği için, işlem yapılırken gerekli ekipman kullanılarak cerrahi personel korundu. Çalışmaya ait verilerin istatiksel analizi SPSS 22,0 programı kullanılarak yapıldı. Sürekli değişkenler ortalama \pm standart sapma, sayımla belirtilen değişkenler ise yüzdelerle gösterildi. Karşılaştırmalarda ki-kare testleri kullanıldı.

\section{BULGULAR}

Çalışmaya alınan hastaların 33'ü $(\% 57,9)$ kadın, 24 'ü $(\% 42,1)$ erkekti. Hastaların yaş ortalaması 27,2 $\pm 6,1$ (18-63) olarak saptand. Erkek hastaların dördü eşcinseldi. Eşcinsel olmayan iki erkek hastada HIV pozitif tespit edildi. Lezyon sayısı 5 ile 18 arasında değişmekte olup, hasta başına ortalama $10,2 \pm 4,5$ lezyon mevcuttu. Lezyonların boyutu $0,2 \mathrm{~cm}$ ile $7 \mathrm{~cm}$ arasında değişmekteydi (Șekil 1,2). Tablo 1'de hastaların demografik verileri detaylarıyla verilmiştir. 57 hastaya 3 haftada bir olmak üzere 6 seans kriyoterapi planlandı. Takip sırasında tedaviye dirençli 14 vaka için haftada 3 gün, 16 hafta olacak şekilde imiquimod tedavisi başlandı. Altı hasta ilerleyen dönemlerde tedaviye devam etmedi. Yaklaşık bir ylllık takipte sadece kriyoterapi uygulanan hastaların $9 \quad(\% 24,3)$ 'unda rekürrens saptanırken, hem kriyoterapi yapılan, hem de imiquimod kullanılan 14 hastanın 3 $(\% 21,4)$ 'ünde nüks saptandı. Yapılan karşılaștırmada istatiksel olarak anlamlı bir fark saptanmadı $(p>0,05)$. Çapı 4 cm'den büyük, anal kanalda bulunan, kriyoterapi yapilamayan 10 hasta cerrahi kliniğinde tedavi edildi.

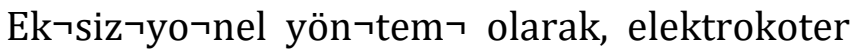
ile cilt altı yağ dokuyu da kapsayacak şekilde total eksizyon ve lezyon tabanına koterizasyon uygulandı. Ameliyat sonrası beş hastada 3. ayda rekürrens geliști ve bu hastalar tekrar cerrahi tedaviye alındılar. Takiplerinde sadece bir hastada nüks saptandl.

Tablo I: Hastaların demografik özellikleri

\begin{tabular}{|c|c|c|c|}
\hline & Kadın & Erkek & Toplam \\
\hline Cinsiyet & $33(\% 57,9)$ & $24(\% 42,1)$ & $57(\% 100)$ \\
\hline \multicolumn{4}{|l|}{ Eğitim Durumu } \\
\hline îlköğretim & $19(\% 57,6)$ & $10(\% 41,7)$ & \\
\hline Ortaöğretim & $10(\% 30,3)$ & $5(\% 20,8)$ & \\
\hline Üniversite & $4(\% 12,1)$ & $9(\% 37,5)$ & \\
\hline \multicolumn{4}{|l|}{ Medeni Hali } \\
\hline Evli & $19(\% 57,6)$ & $10(\% 41,7)$ & \\
\hline Bekar & $14(\% 42,4)$ & $14(\% 58,3)$ & \\
\hline Lezyon sayısı & $5-13(9 \pm 3,8)$ & $7-18(12 \pm 4,7)$ & $5-18(10.2 \pm 4,5)$ \\
\hline
\end{tabular}




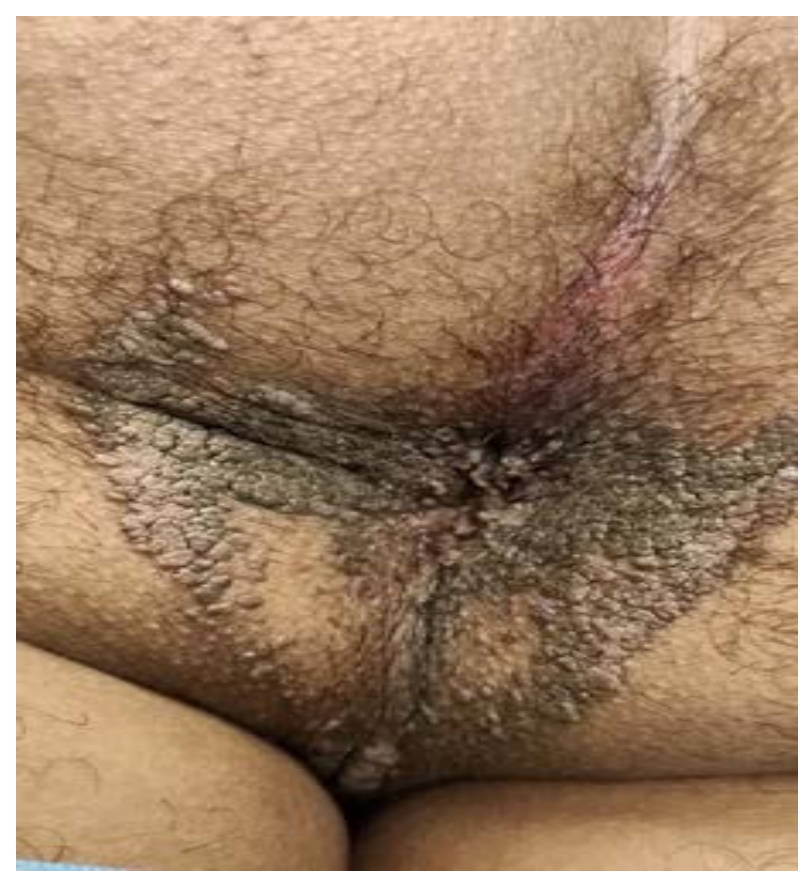

Şekil 1. Perianal bölgede yaygın verrüköz lezyonlar

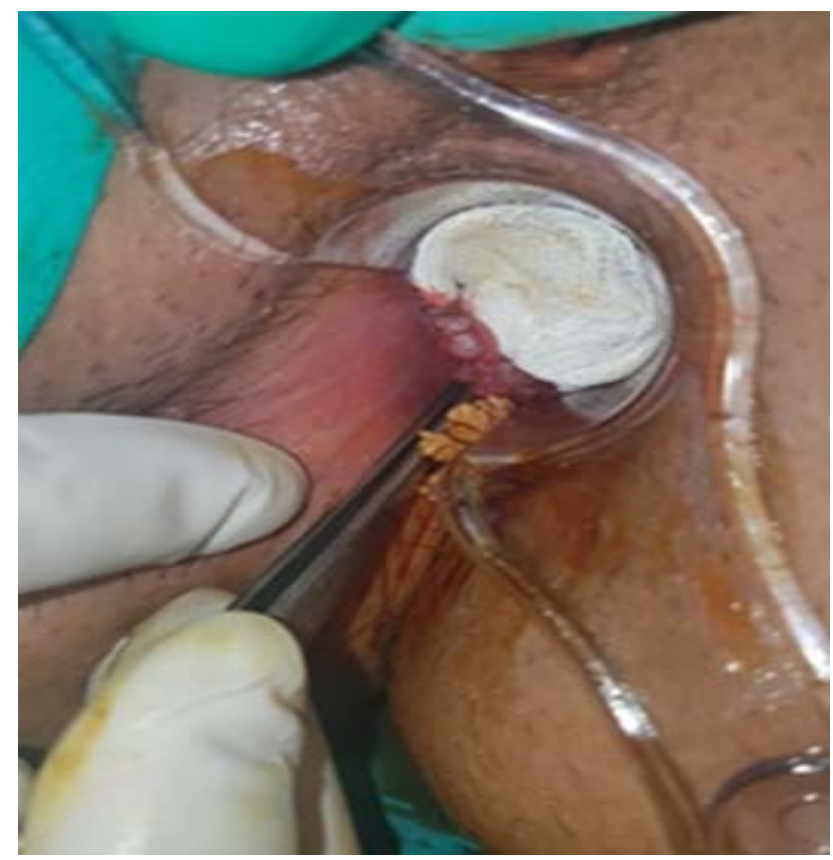

Şekil 2. Anal bölgede yerleşmiş çapı 4 cm'den büyük verrüköz lezyon

Kriyoterapi uygulanan olguların çoğunda, uygulama sonrası oluşan nekrotik doku, tedaviden üç gün sonra düşmeye başladı ve siğil bir haftaya kadar tamamen düştü. Siğilin düşmediği durumlarda, siğilin değișen derecelerde küçüldüğü gözlendi ve bu durumda tedavi tekrarlandı. Uygulama sırasında hafif ile orta şiddette ağrı dışında hastalarda herhangi bir rahatsızlık saptanmadı. Kriyoterapi yapılan hastaların üçünde $(\% 5,9)$ postenflamatuvar hiperpigmentasyon gelişirken, bir hastada hafif skar dokusu gelişti. İmiquimod başlanan 14 hastanın 5'inde hafif irritasyon bulguları vardı, ancak hastalar bu durumu tolere ettiklerini bildirdiler. Cerrahi işlem yapılan hastalarda postopretiv herhangi bir komplikasyon gelişmedi. Lezyon bölgesine günlük pansuman ve antibiyotikli pomad önerildi. Herhangi bir skar dokusu oluşmadı.

\section{TARTIŞMA}

Anal ve perianal bölgede gelişen kondilomların tedavi sonrası nüks oranları oldukça yüksektir. Yapılan çalışmalarda nüks oranı \%4,6-70 arasında bildirilmiștir ${ }^{5-8}$. Uygun tedavi sağlansa dahi HPV ile enfekte hastalarda, semptomsuz dönemler olmasına rağmen enfeksiyonun tamamen yok olduğunu gösteren kanıtlar yoktur. Bu tedaviye direncin temelinde, devam eden cinsel ilişkiden gelişen reenfeksiyon, derin ve gözden kaçan lezyonlar ve HPV'nin uzun süren kuluçka dönemi gibi pek çok faktör suçlanmıştır ${ }^{8}$.

Kondiloma akuminata, HIV virisü ile enfekte olan, özellikle de homoseksüel olan nüfusta daha sık görülmektedir ${ }^{9,10}$. Çalışmamızda 24 erkek hastanın 4'ü eșcinseldi.

Anorektal HPV enfeksiyonu ile yüksek dereceli anal displazi ve skuamöz kanser arasında ilişki bulunmuştur 11,12. Bununla birlikte, HPV enfeksiyonun serviksin, vulva ve vajinanın malign kanseri ve prekanseröz atipik hiperplazi ile de yakından ilişkili olduğu düşünülmektedir5,6,13.

Kondiloma akuminata tedavisinde hasta hekim arasında yakın işbirliği ve tekrarlayan muayene gerekir. $\mathrm{Bu}$ ise tedavi maliyetlerinin artmasina neden olmaktadir. $\mathrm{Bu}$ nedenle ayaktan günübirlik tedavi kondiloma tedavisi için uygun bir seçenektir. Farklı etki mekanizmaları olan ilaçlar kullanılmakta ise de optimal tedavisi 
yoktur. Topikal tedavilerin yanısıra, kriyoterapi ve cerrahi eksizyon da tedavi seçenekleri arasindadır ${ }^{14-16}$.

KA'nın tedavisinde kriyoterapi yaygın olarak kullanılmaktadır. Kriyoterapi sırasında sıvı azot dokuyu dondurur ve böylece nekroza neden olur. Ayrica kriyoterapi, T lenfositlerin kalan canlı siğil dokusuna karşı immünomodülatör etkisini uyarır ${ }^{16,17}$. Kriyoterapinin avantajları, basit, ucuz, nadiren skar veya depigmentasyona neden olmasıdır. Hamilelikte güvenle kullanılabilir ${ }^{16,18}$.

$\mathrm{Bu}$ çalışmada, tedavi için kriyoterapi yöntemi kullanıldı. Tedavi sırasında sıvı azot normal cilt ve mukoza ile temas etti. Bu ciddi hasara neden olmadı; sadece hafif ödem eritem ve yüzeysel erozyon gözlendi. 14 hastada tedaviye direnç nedeniyle topikal imiquimod kullanıldı. Yaklaşık bir yıllık takipte sadece kriyoterapi uygulanan hastalarda rekürrens \%24,3 iken, hem kriyotrapi alan hem de imiquimod alan hastalarda bu oran \%21,4 idi. Kriyoterapi yapılan hastaların üçünde $(\% 5,9)$ postenflamatuvar hiperpigmentasyon gelişirken, bir hastada hafif skar dokusu gelişti.

Anal bölgedeki siğillerin tedavisinde ab $\urcorner$ la $\neg$ tif

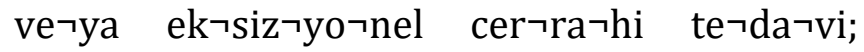
me $\neg$ di $\neg$ kal te $\neg$ da $\neg$ vi $\neg$ ye ya $\neg$ nit ver $\neg$ me $\neg$ yen olıgu $\neg$ lar $\neg$ da ve ya cer $\neg$ ra $\neg$ hi ola $\urcorner$ rak

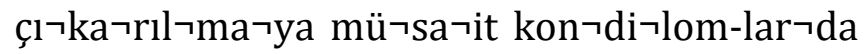
uy $\urcorner g u \neg l a n\urcorner m a k\urcorner t a\urcorner d ı r$. Anal kondilomların tedavisinde cerrahi eksizyon daha iyi sonuçlar verir. Yapılan çalışmalarda; diğer yöntemlerden daha düşük nüks oranına sahip olduğu ve daha fazla konservatif tedavi sağladığı gösterilmiştir. Genel olarak, eksizyon ve fulgurasyon sonrası başarı oranları yüzde 71 ile 93 arasındadır ${ }^{19,20}$. Rekürrens oranları ise \%4 ile \%29 arasında değişmektedir ${ }^{20-22}$. Biz çalışmamızda, anal kanaldan içeride, anal dentadın altına kadar ilerleyen ve $4 \mathrm{~cm}$ den büyük kondilomlar için cerrahi tedavi uygularken, küçük boyutta olan ve yerleşim yeri olarak uygun lezyonlarda da kriyoterapi uyguladık. Çalışmamızda 10 hastaya cerrahi eksizyon uyguland, tedaviyi takiben üçüncü ayda 5 hastada nüks gelişti. Bu hastalara ikinci defa cerrahi uygulandıktan sonra sadece bir hastamızda nüks saptandı. Ameliyat sonrası ağrı analjeziyle tolere edilebilir düzeydeydi. Hiçbir hastada enfeksiyon gelişmedi. İnkontinans vakası bulunmadı ve tüm vakalar estetik açıdan memnundu.

KA'da takip süresi 1 ile 2 yıl arasında değişmektedir. Bu çalışma retrospektif olarak yapıldığı için hastaların uzun dönem klinik sonuçları, gerçek rekürrens oranları ve diğer olası problemlerin gelişip gelişmediği, tam olarak değerlendirilememiștir.

\section{SONUÇ}

Kondiloma Akuminata tedavisinde kriyoterapi küçük ve anatomik olarak uygun lokalizasyonda bulunan lezyonlarda etkilidir. Bununla birlikte, büyük boyutlu ve anal kanal yerleșimli KA'larda cerrahi rezeksiyon; tedavinin daha kısa sürmesini, nüksün daha az olmasını ve hasta memnuniyetini artıran, tedavisi sonrası perianal rekonstrüksiyon için geçerli bir yöntemdir.

Etik Kurul Kararı: SBÜ Gazi Yaşargil Eğitim ve Araştırma Hastanesi Etik Kurulu 02/07/2021813.

Çıkar Çatışması Beyanı: Yazarlar çıkar çatışması olmadığını bildirmişlerdir.

Finansal Destek: Bu çalıșma herhangi bir fon tarafından desteklenmemiștir.

Declaration of Conflicting Interests: The authors declare that they have no conflict of interest.

Financial Disclosure: No financial support was received.

\section{KAYNAKLAR}

1. Ting PT, Dytoc MT. Therapy of external anogenital warts and Molluscum contagiosum: a literature review. Dermatol Ther. 2004; 17: 68-101. 
2. Lacey CJN, Woodhall SC, Wikstrom A, et al. 2012 European guideline for the management of anogenital warts. J Eur Acad Dermatol Venereol. 2013; 27: 263-70.

3. O'Mahony C: Genital warts: current and future management options. Am J Clin Dermatol. 2005; 6: 239-43.

4. Forman D, de Martel C, Lacey CJ, et al. Global burden of human papillomavirus and related diseases. Vaccine. 2012; 30: 12-23.

5. McMurray HR, Nguyen D, Westbrook TF, et al. Biology of human papillomaviruses. Int J Exp Pathol. 2001; 82: 15-33.

6. Partridge JM, Koutsky LA. Genital human papillomavirus infection in men. Lancet Infect Dis. 2006; 6: 21-31.

7. Hildebrand JA, Fischbeck AJ, Hundsdoerfer B, et al. Retrospective analysis of alpha-human papillomavirus (HPV) types in tissue samples from anogenital dysplasias - introduction of the RICH (Risk of HPV-related Carcinoma in HIV+/- patients) score. J Eur Acad Dermatol Venereol. 2020; 34: 37784.

8. Congilosi SM, Madoff RD. Current therapy for recurrent and extensive anal warts. Dis Colon Rectum. 1995; 38: 1101-07.

9. Barrett WL, Callahan TD, Orkin BA. Perianal manifestations of human immunodeficiency virus infection: experience with 260 patients. Dis Colon Rectum. 1998; 41: 606-12

10. Diettrich NA, Cacioppo JC, Kaplan G, et al. A growing spectrum of surgical disease in patients with human immunodeficiency virus/acquired immunodeficiency syndrome. Arch Surg. 1991;126: 860-66.

11. Dailing J, Weiss N, Klopfenestein $\mathrm{L}$, et al. Correlates of homosexual behavior and the incidence of anal cancer. JAMA 1982; 247: 1988-90.

12. Holly E, Whittemore A, Aston D, et al. Anal cancer incidence: genital warts, anal fissure or fistula, hemorrhoids, and smoking. J Natl Cancer Inst. 1989; 81: 1726-31.

13. Villa LL, Costa RL, Petta CA, et al. High sustained efficacy of a prophylactic quadrivalent human papillomavirus types 6/11/16/18 L1 virus-like particle vaccine through 5 years of follow-up. Br J Cancer. 2006; 95: 1459-66.

14. Barton S, Wakefield V, O'Mahony C3, et al. Effectiveness of topical and ablative therapies in treatment of anogenital warts: a systematic review and network meta-analysis. BMJ Open. 2019; 31; 9: $\mathrm{e} 027765$.

15. Gilson RJ, Ross J, Maw R, et al. A multicentre, randomised, double blind, placebo controlled study of cryotherapy versus cryotherapy and podophyllotoxin cream as treatment for external anogenital warts. Sex Transm Infect 2009; 85: 51419.

16. Mistrangelo M, Dal Conte I, Volpatto S, et al. Current treatments for anal condylomata acuminata. Minerva Chir. 2018; 73: 100-06.

17. Mi X, Chai W, Zheng H, et al. A randomized clinical comparative study of cryotherapy plus photodynamic therapy vs. cryotherapy in the treatment of multiple condylo-mataacuminata. Photodermatol Photoimmunol Photomed. 2011; 27: 176-80.

18. Bertolotti A, Milpied B, Fouéré S, et al. Local management of anogenital warts in immunocompetent adults: Systematic review and pooled analysis of randomized-controlled trial data. J Am Acad Dermatol. 2019; 81: 1203-04.

19. Gollock JM, Slatford K, Hunter JM. Scissor excision of anogenital warts. Br J Ven Dis. 1982; 58: 400-01.

20. Jensen SL. Comparison of podophyllin application with simple surgical excision in clearance and recurrence of perianal condylomata acuminata. Lancet. $1985 ; 2$ : 1146-48.

21. Beck DE, Jaso RG, Zajac RA. Surgical management of anal condylomata in the HIV-positive patient. Dis Colon Rectum. 1990; 33: 180-83.

22. Pekmezci E. Higher lesion numbers result in higher recurrence rates: a retrospective cohort study in condylomata acuminata treated with electrocauterization. Georgian Med News. 2019; 289: 51-5. 